\title{
Variability in gas and solute fluxes through deep-sea chemosynthetic ecosystems inhabited by vesicomyid bivalves in the gulf of Guinea
}

\author{
Khripounoff Alexis ${ }^{1, *}$, Caprais Jean-Claude ${ }^{1}$, Decker Carole ${ }^{1}$, Essirard Mikael ${ }^{1}$, \\ Le Bruchec Julie ${ }^{1}$, Noel Philippe ${ }^{1}$, Olu Karine ${ }^{1}$
}

${ }^{1}$ IFREMER/Centre de Brest, Département REM/EEP/Laboratoire Environnement Profond, CS 10070, 29280 Plouzané, France

* Corresponding author: Alexis Khripounoff, Tel.: +33 (0)298 224302 ; email address : alexis.khripounoff@ifremer.fr

\begin{abstract}
:
We have studied two species of vesicomyid bivalves inhabiting different areas of sulfide-rich sediments in association with methane seepage at two pockmarks located at about $650 \mathrm{~m}$ and $3150 \mathrm{~m}$ depth, respectively, along the Gabon-Congo margin, and organic-rich sediments in the deepest zone (4950 $\mathrm{m}$ depth) of the Congo deep-sea fan. Benthic chambers Calmar were deployed on three study sites to assess gas and solute exchanges at the water-sediment interface. We recorded in situ measurements of oxygen, total carbon dioxide, ammonium, methane, and sulfide in two clam beds at each site. At all sites, irrespective of which the vesicomyid species are present, oxygen consumption was high and variable (28-433 mmol m-2 d-1) as was total carbon dioxide emission (36-1857 mmol m-2 d-1). Consequently, the respiratory coefficient also varied greatly, ranging from 0.2 to 5.4. The observed gas and solute fluxes were attributed primarily to the respiration of clams, but microbial and geochemical processes in the sediment may be also responsible for some of the variation among sites. Ammonium production $(7.5-71.8 \mathrm{mmol} \mathrm{m}-2 \mathrm{~d}-1)$ was associated predominantly with nitrogen excretion resulting from vesicomyid metabolism. The O:N index ranged from 2 to 17 indicating that the vesicomyid clams, living in symbiosis with bacteria, have a protein-based metabolism. The cold-seep and organic-rich sediment ecosystems were fuelled by methane expelled from the sediment; methane emission varied from 1.8 to $139 \mathrm{mmol} \mathrm{m}-2 \mathrm{~d}-1$, independently of bivalve biomass. Significant sulfide emission from the sediment was observed only at the shallowest station (156 mmol m-2 d-1). Our in situ measurements confirm that the vesicomyid bivalves have a high capacity for growth and survival across a large gradient of methane and hydrogen sulfide fluxes that occur at $700 \mathrm{~m}$ to $5000 \mathrm{~m}$ depth.
\end{abstract}




\section{Highlights}

- Vesicomyid clams inhabit methane-rich sediments in the deep Gulf of Guinea. Benthic chambers were deployed to assess the gas and solute exchanges of sediment. Total oxygen consumption by the sediment was mostly attributed to the clam respiration. The cold-seep and organic-rich sediment ecosystems were fuelled by methane. Vesicomyid clams have a high capacity for living along a large gradient of methane.

Keywords: Benthic chamber, Cold-seep ecosystem, Reduced sediment, Gas fluxes, Vesicomyid bivalves, Gulf of Guinea 


\section{Introduction}

Exchange and mineralization of organic compounds across the water-sediment interface are regulated by a balance between chemical and biological processes, particularly in cold-seep environments (for review, see Levin, 2005, Boetius and Wenzhofer, 2013). These particular "hotspots" play also a significant role in the deep sea due to the intensity of methane emission and faunal aggregations with high biomass (Wallman et al., 1997; Linke et al., 2005; Sibuet and Olu, 2002; Jørgensen and Boetius, 2007). Several studies on cold seeps showed that megafauna can control the water-sediment exchange by modifying the oxygen and methane flux by bioturbation or/and bioirrigation (Cordes et al., 2005, Sommer et al., 2006, Fisher et al., 2012). Although data on gas fluxes in deep cold-seep areas are rare, several experiments have shown that sediments covered with sulfide-oxidizing bacterial mats have high total oxygen uptake (TOU), which can be up to 25 times higher than in non-seep areas (Linke et al., 2005, Sommer et al., 2006). Based on in situ measurements using benthic chambers, estimated TOU in siboglinid tubeworm fields is one order of magnitude higher than uptake by microbial mats (Felden et al., 2010, Caprais et al., 2010). Studies comparing TOU in vesicomyid beds and adjacent sediment on the Regab pockmark in the Gulf of Guinea provide further support for a substantial megafaunal contribution to the methane cycle via free and symbiotic bacteria (Pop Ristova et al., 2012, Decker et al., 2012).

The efficiency of methane consumption is thought to be enhanced by symbiont-bearing taxa such as siboglinid tubeworms (Cordes et al., 2005, Caprais et al., 2010) or vesicomyid clams (Sommer et al., 2002, Treude et al., 2003, Boetius and Suess, 2004), although neither directly consumes methane. The activity of vesicomyids increases seawater sulfate and oxygen penetration into the sediment, thereby enhancing anaerobic and aerobic methane oxidation deeper in the sediment (Walmann et al., 1997; Fischer et al., 2012, Felden et al., 2014). Thus, at Hydrate Ridge (offshore Oregon, USA) for example, up to $50 \%$ of the methane emissions 
from the water-sediment interface escapes from bacterial mats, but less than $15 \%$ of emissions are lost from vesicomyid habitats (Sommer et al., 2006). Overall, Boetius and Wenzhofer (2013) estimate that $80 \%$ of the methane emitted in low fluid-flow seeps is consumed by chemoautotrophic symbioses at several centimeters depth, while only $20 \%$ is oxidized in intermediate fluid-flow areas covered by thiotrophic bacterial mats, and about $10 \%$ in high fluid-flow areas without benthic life.

This study combined benthic chamber measurements with vesicomyid sampling. It examined the possible relationships between gas fluxes and bivalve biomass and then estimated the respiratory rate of vesicomyids at three deep-sea sites in the Gulf of Guinea. In situ measurements of oxygen, total dissolved inorganic carbon $\left(\Sigma \mathrm{CO}_{2}\right)$ sulfides, methane and ammonium $\left(\mathrm{NH}_{4}{ }^{+}\right)$obtained with the Calmar benthic chamber were combined with vesicomyid density and biomass to address two main questions. (1) Does the metabolism rate vary among vesicomyid species from different sites in the deep Gulf of Guinea? (2) How do the chemical fluxes vary among sites and do they differ between pockmarks and other reduced sediments?

\section{Materials and Methods}

\subsection{Study area}

In the Gulf of Guinea, three different sites were explored during the West Africa Cold Seeps (WACS) cruise (February 2011) aboard the R/V Pourquoi Pas? At each site, two stations were investigated (Fig. 1). The first site, called Regab, is a giant pockmark, $800 \mathrm{~m}$ in diameter, located at $3150 \mathrm{~m}$ depth on the Congo margin (Ondreas et al. 2005, Olu-Le Roy et al. 2007). It is characterized by high habitat heterogeneity, with assemblages of the three major symbiont-bearing taxa encountered at cold seeps: Vesicomyidae (dominant species: 
Christineconcha regab, Cosel and Olu, 2009), Mytilidae bivalves and Siboglinidae polychaetes as well as filamentous bacterial mats. The two stations studied at the Regab pockmark were located in: 1) the center (C) of the pockmark with patchily distributed aggregates of vesicomyid bivalves and 2) the southwestern area (SW) of the pockmark where large vesicomyid beds were observed (Table 1). These stations correspond to site 1 and site 2 in Decker et al. (2012) and are located respectively in the most active part of the pockmark affected by more diffuse methane fluxes (Marcon et al. 2014a).

The second site, called Guiness, includes several small pockmarks, located about $500 \mathrm{~km}$ northwest of Regab, at water depths ranging from 580 to $690 \mathrm{~m}$ (Table 1). The major benthic taxon observed was Vesicomyidae (dominant species Calyptogena valdiviae, Cosel and Olu, 2009). On the first pockmark studied (Kilkenny), very few vesicomyids were observed. The second pockmark (Harp) featured patchy vesicomyid beds associated with filamentous bacterial mats.

The third study site was located at the distal lobe complex of the Congo deep-sea fan (Savoye et al., 2009), at 4750- $5070 \mathrm{~m}$ water depth (Table 1). The Lobe site likely receives large terrestrial organic inputs from the African continent transported via the Congo submarine canyon system (Khripounoff et al., 2003; Vangriesheim et al., 2009). The consequence of this high organic accumulation is rapid reduction of the sediment and a strong oxygen gradient at the sediment surface (Rabouille et al., 2009). This area is characterized by flat brown sediment with several "black pools" of reduced black sediment. Their origin is not clear yet, but the result is upward migration of reduced fluids. A distinctive ecosystem is associated with the black pools and features a biological community that looks like those observed at cold-seeps with microbial mats and vesicomyid bivalves. Generally, vesicomyid beds live at the rim of these black pools, but not in the center, which is partially covered with microbial 
mats. The two stations at this site were located in the main deposition zone of the Congo canyon system that funnels the turbidity material to the terminal lobes. Station A was located at the outlet of the main channel, while station $\mathrm{C}$ was at the far end of the lobe zone, apparently the most active site of the lobe area fed by turbidity currents at present (Dennielou and Droz, pers. com.).

\subsection{Measuring exchanges at the water-sediment interface}

To assess the in situ gas and solute total exchange rate at the water-sediment interface, one Calmar benthic chamber (Caprais et al., 2010) was deployed at each station by the remotely operated vehicle (ROV) Victor. Calmar is a $41 \mathrm{~cm}$ diameter cylinder that is open at one end. The Calmar unit weighs $14 \mathrm{~kg}$ in water. It is equipped with six sampling cells, positioned under the upper side of the chamber, for sampling water $(100 \mathrm{ml})$ at pre-determined intervals for later calculation of fluxes. The cells were constructed with an internal glass lining because glass is impermeable to oxygen. Ejection of the apical pin releases a cocked spring and triggers the closure of the cells by pulling the lower plate upward, using a mechanism similar to that employed for Niskin bottles. The position of the cells under the chamber and their closure mechanism preclude any suction and infiltration of uncontrolled water movement (Caprais et al., 2010). A stirrer ensured that the water in the measurement module remained well-mixed to homogenize the water in the chamber. A sensor optode (Aanderaa ${ }^{\circledR}$ ) was used under each chamber to record in situ oxygen concentration variations.

At each station, a ring of $50 \mathrm{~cm}$ in diameter was first deployed to guide Calmar positioning

(Fig. 2). Then, the Calmar chamber was driven into the sediment to a depth of $10 \mathrm{~cm}$ and enclosed about 18.51 of seawater. The in situ incubation lasted about $3 \mathrm{~h}$ with water being sampled every $30 \mathrm{~min}$. 
Oxygen concentrations were obtained in situ with the optode sensor inside the chamber, which was calibrated by chemical analysis of $10 \mathrm{ml}$ of water sampled in situ with the cells using the modified Winkler titration method (Carrit et al., 1996). $\Sigma \mathrm{CO}_{2}$ was determined from the water samples with the same cells using an infrared gas analyzer (Kaltin et al. 2005). Methane $\left(\mathrm{CH}_{4}\right)$ concentration was analyzed by gas chromatography coupled with a headspace sampler (GC/HSS) (Sarradin and Caprais, 1996). Hydrogen sulfide $\left(\mathrm{H}_{2} \mathrm{~S}\right)$ concentrations were determined by colorimetry (Fonselius, 1983) after precipitation of the sulfide with zinc chloride on board. The detection limit of this method was $\leq 10 \mu \mathrm{mol}^{-1}$. $\mathrm{NH}_{4}^{+}$was analyzed using a manual fluorimetric technique (Holmes, 1999). This analysis is sensitive to the presence of hydrogen sulfide and corrections were calculated to compensate for this effect (Kérouel and Aminot, 1997). Detailed analytical methods are provided in Caprais et al. (2010). Unfortunately, methane and ammonium concentrations were not measured at the Guiness site due to a problem with sample preservation. The fluxes at the water-sediment interface were calculated from the slopes of the linear regressions obtained from six data points for $\mathrm{O}_{2}, \mathrm{CH}_{4}, \Sigma \mathrm{CO}_{2}, \mathrm{NH}_{4}{ }^{+}$and $\mathrm{H}_{2} \mathrm{~S}$ concentration measurements:

Total flux $=\mathrm{S}(\mathrm{V} / \mathrm{A})$

where $\mathrm{S}$ is the slope of the linear regression of gas analysis, $\mathrm{V}$ is the chamber volume and $\mathrm{A}$ the surface area. The respiratory coefficient (RQ) was calculated as $\Sigma \mathrm{CO}_{2} / \mathrm{O}_{2}$ and the O:N index was calculated according to their atomic equivalents.

The efficiency of the benthic filter for methane is estimated as TOU/2 divided by the calculated total $\mathrm{CH}_{4}$ flux for each station using the Boetius and Wenzhofer (2013) equation.

\subsection{Density, biomass, and respiration rate calculation of vesicomyids}


At each site, the vesicomyid density (number of individuals. $\mathrm{m}^{-2}$ ) was estimated with two different methods, one based on photographs and the other on quantitative sampling. First, a ring of $50 \mathrm{~cm}$ in diameter was deployed on a bivalve aggregate. Then, photographs were taken to estimate the number of vesicomyids on the sediment within this ring before deployment of the benthic chamber (Fig. 2). Vesicomyids were considered dead when shells were open and were not included in the density calculation. The second method involved sampling vesicomyids and sediment in the ring using a blade corer $\left(0.036 \mathrm{~m}^{2}\right)$ after the Calmar chamber had been recovered. Mean clam density was estimated from these two measurements taken each time the Calmar chamber was deployed, except at the Guiness Kilkenny station where the corer did not work and the density was estimated based only on the photograph counting method. On board, the vesicomyid species sampled with the corer were identified, washed with seawater and preserved in $4 \%$ buffered formalin or frozen. In the laboratory, biomass (dry weight $=\mathrm{dw}$ ) of Vesicomyidae sampled with the blade corer was determined from tissues removed from the shells and then dried for $24 \mathrm{~h}$ at $60{ }^{\circ} \mathrm{C}$. For each Calmar deployment, the mean and the standard deviation of biomass $\left(\mathrm{g} \mathrm{dw} . \mathrm{m}^{-2}\right)$ were calculated using the mean density of vesicomyids, estimated from photographs and blade cores, and mean individual tissue dry weight.

Assuming that exchange rates at the water-sediment interface were essentially due to bivalve metabolism under each Calmar, $\mathrm{O}_{2}$ uptake, $\Sigma \mathrm{CO}_{2}$ production and $\mathrm{NH}_{4}{ }^{+}$excretion by vesicomyids were calculated using the following expression, (diffusive fluxes of $\mathrm{CO}_{2}$ and $\mathrm{NH}_{4}^{+}$in the sediment was neglected, see section 4.2):

Respiration or excretion rate of vesicomyids $\left(\mu \mathrm{mol} \mathrm{g} \mathrm{g}^{-1}\right)=\mathrm{B}^{-1}\left[\mathrm{Vt}^{-1}\left(\mathrm{C}_{2}-\mathrm{C}_{1}\right)\right]$, where $\mathrm{B}$ is the total dry weight biomass $(\mathrm{g})$ of vesicomyids under the Calmar chamber; $\mathrm{C}_{1}$ and $\mathrm{C}_{2}$ are gas or ammonium concentrations in the Calmar chamber at time 1 and $2\left(\mu \mathrm{mol} \mathrm{l}^{-1}\right)$; V 
is the volume of water isolated within the Calmar chamber inserted into the sediment; $t$ is the time interval $(\mathrm{h})$ between measurements.

\section{Results}

\subsection{In situ gas and solute fluxes}

At the three study sites (Guiness, Regab, Lobe), the incubations were made under oxic bottom water conditions. The TOU, measured from sediment covered with vesicomyids, was between 28.5 and $433.4 \mathrm{mmol} \mathrm{O}_{2} \mathrm{~m}^{-2} \mathrm{~d}^{-1}$ (Table 2). The minimum $\mathrm{O}_{2}$ consumption was observed at the Guiness Kilkenny station and the maximum at the Regab C station. High intra-site variations are also observed, particularly at Guiness site: $28.5 \mathrm{mmol} \mathrm{O}_{2} \mathrm{~m}^{-2} \mathrm{~d}^{-1}$ at Kilkenny station and $271 \mathrm{mmol} \mathrm{O}_{2} \mathrm{~m}^{-2} \mathrm{~d}^{-1}$ at Harp station.

The flux of $\Sigma \mathrm{CO}_{2}$ ranged from 36 (Lobe A) to 1857 (Lobe C) $\mathrm{mmol} \mathrm{CO}_{2} \mathrm{~m}^{-2} \mathrm{~d}^{-1}$. The RQ ratio of the sediment varied between 0.2 (Regab W) and 5.4 (Lobe C) at the different stations.

During incubation, $\mathrm{NH}_{4}{ }^{+}$concentration increased significantly. The emission rate observed under the Calmar chamber ranged from 2.9 (Regab SW) to 71.8 (Lobe C) $\mathrm{mmol} \mathrm{NH}_{4}^{+} \mathrm{m}^{-2} \mathrm{~d}^{-1}$ (Table 2). The ratio between oxygen consumption and ammonium excretion (O:N index) ranged from 2 (Lobe C) to 17 (Regab C).

$\mathrm{CH}_{4}$ emission was always detected at the Regab and Lobe sites, varying from 1.8 to 139 mmol m $\mathrm{m}^{-2} \mathrm{~d}^{-1}$. The highest $\mathrm{CH}_{4}$ flux was observed at Lobe $\mathrm{C}$ and the lowest at the Lobe $\mathrm{A}$ with one order of magnitude between these two stations (Table 2). The efficiency of the benthic filter for $\mathrm{CH}_{4}$ was $>50 \%$ (55\% and $98 \%$ at Regab and Lobe sites, respectively). 
Significant sulfide flux was only detected at the Guiness Harp station $\left(156 \mathrm{mmol} \mathrm{m}^{-2} \mathrm{~d}^{-1}\right)$, given that the detection level of our analytical method was $20 \mathrm{mmol} \mathrm{m}^{-2} \mathrm{~d}^{-1}$.

All these results are summarized in Table 2 and an example of data obtained using the Calmar chamber at Regab C station is shown in Figure 3.

\subsection{Vesicomyid density and biomass}

Both methods used to calculate vesicomyid density indicated that the results obtained with the corer were generally higher by 25 to $75 \%$ than those obtained by counting vesicomyid number from photographs, with the exception of the Regab C station where the density calculation by photographs was higher (Table 3 ). This is mainly due to the heterogeneity of bivalve density within the circle, perhaps because the cores were taken in the center of the circle when the density was usually the highest (Fig. 2). Even when they were totally buried, the siphons of the clams were visible on the photographs. At the Regab site, vesicomyid biomass (C. regab) measured under the Calmar chamber was higher at the $\mathrm{C}$ station than at the SW station with values of 1699 and $729 \mathrm{~g}$ dry weight. $\mathrm{m}^{-2}$, respectively. At the Guiness site, vesicomyid density (C. valdiviae) was even more heterogeneous with a higher density at the Harp station compared to the Kilkenny station, respectively 300 and 75 ind. $\mathrm{m}^{-2}$. At the Lobe site, also colonized by $C$. regab, vesicomyid densities under the Calmar chamber were very high, ranging from 518 to 742 ind. $\mathrm{m}^{-2}$. Individual biomass also varied among stations and species (Table 3). Individual dry weight of C. regab was significantly higher at the Regab stations $\left(2.33-2.91 \mathrm{~g} \mathrm{dw}\right.$ ind $\left.^{-1}\right)$ than at the Lobe stations $\left(0.84-1.55 \mathrm{~g} \mathrm{dw}\right.$ ind $\left.^{-1}\right)$ (KruskalWallis: $\left.\mathrm{X}^{2}=70, \mathrm{p}<0.001\right)$. However, total biomass was not different between these two sites and was higher than at the Guiness site (Table 3). 


\subsection{Vesicomyid metabolism}

Vesicomyid clams dominated the living biomass under each Calmar chamber at all six stations. Based on the preliminary assumption that dominant biomass accounts for most of the metabolic activities observed, we postulated that vesicomyid metabolism was responsible for the main fluxes of $\mathrm{O}_{2}, \Sigma \mathrm{CO}_{2}$ and $\mathrm{NH}_{4}{ }^{+}$between the sediment and the overlying bottom water (see section 4.2). Based on this assumption, the vesicomyid respiration rate was calculated in terms of dry weight (Fig. 4) given the estimated biomass under each Calmar chamber (Table 3). Across the six stations, calculated oxygen consumption by vesicomyids could vary from $0.17 \mathrm{mmol} \mathrm{O}_{2} \mathrm{dw} \mathrm{g}^{-1} \mathrm{~d}^{-1}$ (Lobe A) to 1.35 mmol $\mathrm{O}_{2} \mathrm{dw} \mathrm{g}^{-1} \mathrm{~d}^{-1}$ (Guiness Harp), with a mean bivalve oxygen respiration rate of $0.34 \pm$ $0.14 \mathrm{mmol} \mathrm{O}_{2} \mathrm{~g}^{-1} \mathrm{dw} \mathrm{d} \mathrm{d}^{-1}$. This mean value was calculated without Guiness Harp data because the consumed $\mathrm{O}_{2}$ at this station was certainly the result of the sulfur oxidation as well as vesicomyid respiration. Significant sulfide flux was detected at this station. $\Sigma \mathrm{CO}_{2}$ was predominantly produced by the respiration of the vesicomyid biomass and its production was relatively homogeneous between the different stations (from 0.05 to 0.4 mmol $\left.\mathrm{CO}_{2} \mathrm{dw} \mathrm{g}^{-1} \mathrm{~d}^{-1}\right)$ with the exception of Lobe $\mathrm{C}\left(2.64 \mathrm{mmol} \mathrm{CO}_{2} \mathrm{dw} \mathrm{g}^{-1} \mathrm{~d}^{-1}\right)$. The RQ ratio was very low (0.2-0.6) except at Guiness Kilkenny and Lobe C, which showed ratios of $>3$ (Table 2). During incubation, vesicomyid excretion was probably the main factor contributing to the increase in $\mathrm{NH}_{4}{ }^{+}$concentration because these bivalves were the main contributors to biomass in the incubated sediment. Under this assumption, the $\mathrm{NH}_{4}^{+}$ production by bivalves was $8.8 \pm 3.2 \mu \mathrm{mol} \mathrm{NH}_{4}{ }^{+} \mathrm{dw} \mathrm{g}^{-1} \mathrm{~d}^{-1}$. The value obtained at Lobe $\mathrm{C}$ was not included in this calculation because $\mathrm{NH}_{4}{ }^{+}$flux was too high at this station $(102.1$ $\left.\mu \mathrm{mol} \mathrm{NH}{ }_{4}^{+} \mathrm{dw} \mathrm{g}^{-1} \mathrm{~d}^{-1}\right)$. It was product of the denitrification process as well as of the vesicomyid excretion (Fig. 5). The ratio between $\mathrm{O}_{2}$ consumption and $\mathrm{NH}_{4}{ }^{+}$excretion rates 
with respect to biomass (i.e. the $\mathrm{O}: \mathrm{N}$ index) was 18 on average (without Lobe $\mathrm{C}$ data, see above).

\section{Discussion}

\subsection{Distribution of vesicomyids}

Previous studies of the composition and distribution of cold-seep faunal communities at local and regional spatial scales have revealed the central role of energy availability, in the form of methane, sulfide and oxygen fluxes, and the type of seafloor substrate (Sahling et al., 2002; Sibuet and Olu-Le Roy, 2002; Olu-Le Roy et al., 2007; Levin et al., 2010; Ritt et al., 2011; Decker et al., 2012; Fischer et al., 2012). Vesicomyid bivalves are widespread in chemosynthetic ecosystems, and occur at most known cold-seep sites (Krylova and Sahling, 2010). They are associated with low methane and sulfide fluxes, compared to bacterial mats

(Sahling et al., 2002; Levin et al., 2003) and mussel beds (Olu-Le Roy et al., 2007, Marcon et al., 2014b). Their distribution is often patchy and their density can reach up to 1000 ind. $\mathrm{m}^{-2}$, with a biomass ranging from 10 to $30 \mathrm{~kg}$ wet weight $\mathrm{m}^{-2}$ (Hashimoto et al. 1989, Olu et al. 1996, Sibuet and Olu-Le Roy, 2002, Decker et al., 2012).

Our results show variation in density and mean individual biomass with higher values at the Regab C station compared to the SW station (Table 3). This difference was also observed in term of methane flux, higher in the center compared to the periphery (Charlou et al. 2004; Ondreas et al.2005), a difference that has persisted at least over the last 10 years, as suggested by faunal distributions (Marcon et al. 2014b) as well as by several benthic chamber deployments (Decker et al., 2012; Pop Ristova et al., 2012; this paper). A previous study at the same site in 2008 showed lower densities at the Regab C station than at the SW station, 
but individual biomass was higher. Density differences through time may reflect changes in fluid-flow, which is assumed to be transient at the scale of vesicomyid clusters (Marcon et al. 2014b). Measured $\mathrm{CH}_{4}$ fluxes, which were always higher at Regab station $\mathrm{C}$ than at station SW, can explain these differences in clam biomass.

The Lobe site was also colonized by $C$. regab, but individual dry weight and size were significantly lower at the Lobe site, particularly at Lobe C, than at the Regab site (Table 3). The reason of this size difference is not known. One explanation is that clam samples from Lobe might be younger than those from Regab. This applies particularly at Lobe A, where the occurrence of a few dense patches of vesicomyids of the same size without any empty shells suggests recent bivalve settlement and likely an unstable environment. Vesicomyid beds comprising both living and dead individuals, which were more abundant at Lobe A, could be sustained by lower but more regular methane fluxes.

Our measurements show that the environment-related chemical parameters varied widely between sites and intra-sites. Thus, energy availability and environmental conditions are not uniform, and may have different influences on the physiology and growth of bivalves, leading to the observed size differences of $C$. regab. At the Guiness site, both stations were dominated by another vesicomyid species, $C$. valdiviae, which formed small aggregates of few individuals, particularly at Kilkenny station. Guiness site was also characterized by high sulfide concentrations at the Harp station, which could modify the ecological condition at this station. The vesicomyids were small, similar to those sampled at the Lobe $\mathrm{C}$ station. Crabs and fish are abundant around vesicomyids and predation may also limit the bivalve population, as suggested for other shallow cold-seep sites (Sahling et al., 2002).

\subsection{Interaction between gas and solute consumption-emission rates and vesicomyids}


TOU across the water-sediment interface mainly reflect the direct consumption of oxygen by benthic fauna $\left(\mathrm{CH}_{2} \mathrm{O}+\mathrm{O}_{2} \rightarrow \mathrm{CO}_{2}+\mathrm{H}_{2} \mathrm{O}\right)$, by aerobic methanotrophic bacteria $\left(\mathrm{CH}_{4}+\mathrm{O}_{2} \rightarrow\right.$ $\left.\mathrm{CO}_{2}+2 \mathrm{H}_{2} \mathrm{O}\right)$, by sulfide oxidation $\left(\mathrm{HS}^{-}+2 \mathrm{O}_{2} \rightarrow \mathrm{SO}_{4}{ }^{2-}+\mathrm{H}^{+}\right)$, by nitrification $\left(\mathrm{NH}_{3}+\mathrm{O}_{2} \rightarrow \mathrm{NO}_{2}^{-}\right.$ $\left.+3 \mathrm{H}^{+}\right)$and by chemical oxidation $\left(\mathrm{Fe}\right.$ or $\mathrm{Mn}+\mathrm{O}_{2} \rightarrow \mathrm{FeO}_{2}$ or $\left.\mathrm{MnO}_{2}\right)$. In situ measurements of $\mathrm{O}_{2}$ fluxes at the water-sediment interface in cold seeps show large variations in gas exchange through the sediment (see review by Boetius and Wenzhofer, 2013) and the contribution of the megafaunal biomass to this oxygen budget has not been well characterised. In previous studies at the Regab site, TOU values at vesicomyid clusters ranged from 259 to $384 \mathrm{mmol} \mathrm{O}_{2}$ $\mathrm{m}^{-2} \mathrm{~d}^{-1}$ (Decker et al., 2012, Pop Ristova et al., 2012), whereas in this study, it varied from 272 to $433 \mathrm{mmol} \mathrm{O}_{2} \mathrm{~m}^{-2} \mathrm{~d}^{-1}$. At other seep sites also colonized by vesicomyid clams, relatively low TOU rates have been reported, i.e. in the range of 2.0 to $5.1 \mathrm{mmol} \mathrm{O}_{2} \mathrm{~m}^{-2} \mathrm{~d}^{-1}$ at Hydrate Ridge off Oregon (USA) (Sommer et al., 2006) or $21 \mathrm{mmol} \mathrm{O}_{2} \mathrm{~m}^{-2} \mathrm{~d}^{-1}$ in the Japan Trench (Felden et al., 2014). However, without indications of bivalve density or biomass in these studies, the comparison is not easy. This large disparity in TOU values in cold seeps can be attributed to the heterogeneity of the faunal density under the benthic chambers and bacterial oxidation of organic matter, sulfide and methane at the sediment surface (Boetius and Wenzhofer, 2013). Distinct biogeochemical regimes and gas exchange involving oxygen, for example, can be modified by the seafloor communities found at the water-sediment interface. In our study, the large predominance of vesicomyid biomass under each Calmar chamber suggests that vesicomyids were the main $\mathrm{O}_{2}$ consumers. This assumption also made by Boetius and Wenzhofer (2013) for cold seeps colonized by high densities of symbiotic animals. However, we measured two processes in vesicomyid respiration: oxygen uptake by the host for organic material catabolism as well as oxygen uptake for sulfide oxidation carried out by the symbiotic bacteria. Sulfide oxidation provides the energy for primary production carried out by the symbionts. If we consider that oxygen consumption was calculated for the 
entire clam tissue dry weight (i.e. host and its symbionts), the respiratory rate of the vesicomyids was estimated to be $0.34 \pm 0.14 \mathrm{mmol} \mathrm{O}_{2} \mathrm{~g}^{-1} \mathrm{dw} \mathrm{d}^{-1}$ (Fig. 4). This value is probably an overestimate because an unknown proportion of $\mathrm{O}_{2}$ may be consumed by other reactions: consumption by small benthic organisms (macrofauna, meiofauna, and microfauna), by a variety of methanotrophic bacteria, by nitrification, or by chemical oxidation. The intensity of these oxidation reactions in the sediment represents a major uncertainty for our estimates of $\mathrm{O}_{2}$ consumption. In vesicomyid beds of the Cascadia margin, heterotrophic macrofauna account for $8 \%$ of the biomass (Sahling et al. 2002). Similar proportions were found in vesicomyid beds of Regab (Decker et al., 2012). Usually, the ratio between macrofauna and symbiotic bivalve biomass is low in cold seeps, and therefore macrofaunal metabolism is likely negligible for the TOU estimation in this study. The contribution of aerobic oxidation of methane (AeOM) and sulfide oxidation by bacteria to the total $\mathrm{O}_{2}$ consumption is not known in this study and can be variable according to the intensity of the fluid-flow and the related microbial and faunal colonization (Boetius and Wenzhofer, 2013). In our case, no bacterial mat was observed under the Calmar chamber with the clams and the thickness of the oxidized sediment was less than $1 \mathrm{~mm}$ (visual observations), thereby limiting the possibility of AeOM activity (Sommer et al., 2006).

The respiration rate of deep-sea, cold-seep bivalves obtained in this study $\left(0.34 \mathrm{mmol} \mathrm{O}_{2} \mathrm{~g}^{-1}\right.$ $\left.\mathrm{d}^{-1}\right)$ is similar that of deep-water Limidae bivalve respiration rates of $0.32 \pm 0.17 \mathrm{mmol} \mathrm{O}_{2} \mathrm{~g}^{-1}$ $\mathrm{dw} \mathrm{d} \mathrm{d}^{-1}$ measured at a temperature of $8^{\circ} \mathrm{C}$ (Jarnegren and Altin 2006). Several factors affect the respiration rate of most bivalves, including size, temperature, salinity, food availability and gametogenic stage. Jarnegren and Altin (2006) proposed that low respiration rates of deep bivalves are a result of the low and stable temperature at which they live. In our study, oxygen is consumed by two entities in the deep-sea clams, the host and its symbionts, whereas other bivalves for which respiration data are available, including limid bivalves, lack symbionts. 
Nevertheless, our results do not conclusively demonstrate that the deep-sea vesicomyid host has a lower metabolism than the deep-water Limidae bivalve. Several other factors can also affect the respiration rate of most bivalves, such as size and age. However, significant changes in the respiration rate in $C$. regab were observed despite no differences in the size of this species between the Regab and Lobe sites. The Guiness Harp station was anomalous because the calculated respiration rate was higher by an order of magnitude compared to the Guiness Kilkenny station at the same site. This difference cannot be attributed solely to an underestimation of bivalve biomass. The Guiness Harp station was the only station at which a high sulfide flux was measured, possibly indicating recent changes in the overall methane efflux intensity. Therefore, the respiration rate of the vesicomyids and bacterial activity may have increased, explaining this high observed oxygen consumption rate. An increase in the activity of other free-living sulfide-oxidizing bacteria (e.g. nitrite/nitrate for sulfide oxidation) could also partly contribute to the high TOU values.

The in situ incubation method utilised in this study simultaneously measures $\mathrm{O}_{2}$ consumption and $\Sigma \mathrm{CO}_{2}$ production, and makes it possible to calculate for the first time the RQ in a deepsea cold seep. Physiological indexes such as RQ best describe the changes in the catabolic balance between the various substrates that occur over the course of a life cycle. This ratio also provides information on the catabolism and the energy sources of deep vesicomyids. RQ varies among organisms and it is mainly determined by the elemental composition of the food source and the type of metabolism (Hatcher, 1989). The average value found in the literature for various marine invertebrate species is 0.75 (Koopmans, 2010). In our experiments, $\Sigma \mathrm{CO}_{2}$ was not only produced by bivalves, but also by the oxidation of methane (Boetius et al., 2000) and the degradation of organic matter by bacteria activity. Furthermore, $\Sigma \mathrm{CO}_{2}$ can be consumed by methanogenic bacteria (Whiticar, 1999). The calculated RQ values were very low at four of the stations (Table 2), ranging from 0.2 to 0.6 at the Regab C and SW, Lobe A 
and Guiness Harp stations. This can be explained by a significant $\Sigma \mathrm{CO}_{2}$ flux decrease, possibly caused by carbonate precipitation (Aloisi et al., 2002). The benthic chamber, which accumulates carbon during incubations, can artificially accelerate this process in situ. Conversely, the excess of $\Sigma \mathrm{CO}_{2}$, revealed by very high RQ ratios of 3.3 and 5.4 at two stations (Guiness Kilkenny and Lobe C), may be due to an increase in anaerobic mineralization of organic matter and anaerobic oxidation of methane. Thus, the great variations in $\Sigma \mathrm{CO}_{2}$ flux observed in this study at a small spatial scale illustrate the complexity of the ecosystem activity dominated by vesicomyids in the deep sea.

The excretion of ammonium, a necessary consequence of protein breakdown, is another biochemical process involved in the metabolism of marine organisms. However, direct measurements of ammonium excretion rate by bivalves in cold seeps have never previously been reported. However, previous studies at Regab (Pop Ristova et al., 2012) showed that sediments, with living clams, had high ammonium concentration close to the foot of these bivalves. These results indicate probably a local excretion by the clams. If we assume, like Pop Ristova et al. (2012), that the ammonium measured under the Calmar chamber can be essentially attributed, like the $\mathrm{O}_{2}$ and $\Sigma \mathrm{CO}_{2}$ fluxes, to vesicomyid metabolism, then the average excretion rate of these bivalves was on average to $8.8 \mu \mathrm{mol} \mathrm{NH} 4^{+} \mathrm{g} \mathrm{dw} \mathrm{d}^{-1}$ (calculated without Lobe $\mathrm{C}$ data, see results section 3.3). This value is lower than the measurements reported for shallow-water bivalves $\left(>20 \mu \mathrm{mol} \mathrm{NH} 4^{+} \mathrm{g} \mathrm{dw} \mathrm{d} 1\right.$; Huang and Newell, 2002). The high ammonium flux measured at the Lobe $\mathrm{C}$ station can be explained mainly by the fact that vesicomyid excretion rate are higher than at the other sites. However, bacteria living in sediment zones with abundant dissolved sulfide can also use the stored nitrate as an electron acceptor to produce ammonium (Lichtschlag et al., 2010). The O:N ratio encompasses variation in the rates of oxygen consumption and ammonium excretion. It represents a useful indicator of the balance between protein, lipid and carbohydrate 
catabolism (Bayne 1976) or the nutritional state of individuals (Hatcher, 1991; Grant and Thorpe, 1991). A high protein-based metabolism observed in carnivorous-omnivorous organisms generally results in a low $\mathrm{O}$ : $\mathrm{N}$ ratio compared to diets high in lipids or carbohydrates (Babarro et al., 2000). The O: $\mathrm{N}$ ratio for ribbed mussels ranges from 45 to 118 (Wilbur and Hilbish, 1989), values that are greater than those reported here, which are between 2 and 17. This difference can be attributed to several factors. The first is the fact that the TOU and total $\mathrm{NH}_{4}{ }^{+}$flux values used to calculate the O:N ratio are attributed only to the vesicomyid metabolism, although they also incorporate the activities of the macrofauna, meiofauna and bacteria under the Calmar chamber. Secondly, the mussel diet generally consists of carbon-based compounds, such as carbohydrates and lipids, as the primary catabolic substrate (Huang and Newell, 2002), whereas the vesicomyids, in common with carnivores, assimilate nutrients rich in proteins via their symbiotic bacteria.

\subsection{Methane and sulfide fluxes}

The distribution of clams at cold seeps or in organic-rich settings is controlled by biogeochemical processes in the sediments, which are initially influenced by the subsurface supply of methane (Fig 5a). However, the consequence of benthic ecosystem activity on the methane flux in cold seeps is unknown. A review of methane emission rates from cold seeps in various geographical regions (Boetius and Wenzhofer, 2013) shows a large range of methane fluxes, as observed in this study, with a maximum $>300 \mathrm{mmol} \mathrm{m}^{-2} \mathrm{~d}^{-1}$ in a dense bed of ampharetid polychaetes on the Hikurangi Margin (New Zealand) (Sommer et al., 2010) and at the Hakon Mosby mud volcano (Norway) (Felden et al., 2010). In the Regab vesicomyid beds, we observe $\mathrm{CH}_{4}$ flux ranging from 12.3 to $45.8 \mathrm{mmol} \mathrm{m}^{-2} \mathrm{~d}^{-1}$, values which are higher than those observed by Decker et al. (2012). Pop Ristova et al. (2012) also reported that $\mathrm{CH}_{4}$ fluxes are hardly detectable $\left(<1\right.$ to $\left.3 \mathrm{mmol} \mathrm{m}^{-2} \mathrm{~d}^{-1}\right)$ at the same stations in the Regab site. These previous studies, together with the present data, confirm the extreme spatial 
heterogeneity of fluxes at the scale of few $\mathrm{cm}$ in cold seeps, as well as their possible temporal variability. High methane flux was observed at the Lobe $C$ station $\left(139 \mathrm{mmol} \mathrm{m}^{-2} \mathrm{~d}^{-1}\right)$. The Lobe site has special features because it is a major deposit center for terrestrial organic material transported by the Congo canyon (Vangriesheim et al., 2009). The organic matter can be decomposed into $\mathrm{CH}_{4}$ and $\mathrm{CO}_{2}$ by a microbial food chain that terminates with methanogens that produce biogenic methane (Fig. 5b). Another source of methane, coming from deep reservoirs (thermogenic methane), has not been demonstrated at the Lobe site. Vesicomyids do not contribute directly to methane oxidation in the sediment, but can potentially do so indirectly by physical interaction with their environment, e.g. bioturbation. AeOM and AOM, already detected at Regab (Pop Ristova et al., 2012), have not been investigated yet at the Lobe site (Fig. 5b) and their presence has not been proven.

The concept of a benthic filter for methane is based on AOM and AeOM in the seafloor ecosystem (Sommer et al., 2006, Knittel and Boetius, 2009). Our results (Table 2) indicate a filter efficiency of $>50 \%$ (55-98 \%), indicating a system with low fluid-flow (Boetius and Wenzhofer, 2013) and showing that the majority of the dissolved methane flowing in the sediment is used by the benthic biota before it is diffused into the sea-water at Regab and Lobe A. Lobe C was a high-methane flow area, which explains the lower filter efficiency of methane at this station and the very low sulfide flux (Lichtschlag et al., 2010).

In this study, the detection limit of the sulfide flux was $\leq 20 \mathrm{mmol} \mathrm{m}^{-2} \mathrm{~d}^{-1}$. Given this limitation, sulfide flux was only detected at the Guiness Harp station $\left(156 \mathrm{mmol} \mathrm{m}^{-2} \mathrm{~d}^{-1}\right)$; none was observed at the Kilkenny station, where the vesicomyid biomass was more scattered. High sulfide concentration may limit bivalve biomass due to the high toxicity of this compound; very low or no sulfide flux also can be found close to vesicomyid habitats at other cold seeps (Cordes et al., 2010). Thus, our results are inconclusive regarding 
interactions between bivalves and the sulfide flux. The sulfide front often does not reach the surface of the seep sediment (Sommer et al., 2008) because, in low fluid-flow, sulfideoxidizing bacterial mats act as an effective filter at the water-sediment interface or/and fluxes of oxygen and nitrate are sufficient for a complete consumption of sulfide by thiotrophs (Jørgensen and Nelson, 2004; Lichtschlag et al., 2010). Our results show that this filter, supported by megafauna, appears to be efficient. At the Regab site, Pop Ristova et al. (2012) report a sulfide flux of $5 \pm 0.6 \mathrm{mmol} \mathrm{m}^{-2} \mathrm{~d}^{-1}$ on bivalve patches. This low value is under our detection level, and explains why we failed to detect sulfide fluxes at the same site. On Hydrate Ridge, values of $7 \pm 2.4 \mathrm{mmol} \mathrm{m} \mathrm{m}^{-2}$ have been reported (Treude, 2003). The energy source for bivalves living in cold seeps comes from the sulfide production via AOM (Fig. 5a). In the black pools of Lobe, this energy likely comes first from rapid diagenesis of organic carbon in anaerobic conditions with production of methane and sulfide that are used by the microbial population (Fig. 5b).

\section{Conclusions}

In the different "hot spots" studied here, bivalves greatly influenced the total fluxes of $\mathrm{O}_{2}$, $\Sigma \mathrm{CO}_{2}$ and $\mathrm{NH}_{4}{ }^{+}$at the water-sediment interface. We showed that the respiration rate of deepsea vesicomyids calculated in this study does not differ along the investigated depth gradient (600-5000m depth) and was similar to that of bivalves living in cold deep-sea habitats.. We observed only one station with a significant sulfide flux, but a methane flux was always detected under the benthic chambers. The benthic filter due to the anaerobic and aerobic consumption of methane by the seafloor ecosystem is very efficient in seep and organic-rich sediments. Our results illustrate the complexity of sediment gas-exchanges processes in cold seeps or deep-sea organic-rich settings such as deep canyon fans (Fig. 5). It is now crucial to 
perform sediment pore-water analysis in the same place as these benthic chamber measurements to estimate the proportion of flux due to the various chemical and biological mechanisms. Despite its limitations, this study suggests new avenues for investigating the role of benthic fauna in buffering chemical fluxes at the water-sediment interface. We show that advances in deep-sea technology can lead to an improved, albeit still limited, understanding of the biogeochemistry and biology of areas of abyssal methane seepage.

Vesicomyid clams are among the dominant chemosynthetic megafauna in seep and organicrich settings. As a result of their size and abundance, they are likely to be involved in numerous interactions with the surrounding environment and other organisms. Limited ecological data for vesicomyids in the Gulf of Guinea provides evidence of unique ecological attributes that may be representative of vesicomyids in general. Closer study of the ecology of these species can improve our understanding of vesicomyid adaptations to deep-sea sulfiderich environments. These bivalves can perhaps serve as a model for other chemosynthetic taxa. In recent years, sulfide-rich environments have revealed new ecosystems, new habitats, and new species. In many ways, these discoveries are a prelude to advances in our understanding of processes underlying life in such extreme environments. The next step is to isolate vesicomyid clams from the sediment in a benthic chamber to eliminate the influence of the sedimentary environment.

\section{Acknowledgments}

We thank the captain and the crew of the R/V Pourquoi Pas? and the ROV Victor team. The scientific and the technical staff participating in the WACS cruise are also gratefully acknowledged. We thank L. Ruffine for his comments and suggestions. This work was 
partially supported by the French National Research Agency for the project ANR 11 BS56 030 02: Transfert de carbone organique et fonctionnement des écosystèmes dans les lobes terminaux de l'éventail sous-marin du Congo (Transfer of organic carbon and ecosystem functioning in the terminal lobes of the submarine Congo). We thank the four reviewers for their comments that help us to improve the manuscript.

\section{References}

Aloisi , G., Bouloubassi, I., Heijs, S.K., Pancost, R.D., Pierre, C., Sinninghe Damste, J.S., Gottschal, J.C., Forney, L.J., Rouchy, J.-M., 2002. CH4-consuming microorganisms and the formation of carbonate crusts at cold seeps. Earth Planet. Sci. Lett. 203, 195-203.

Babarro, J.M.F., Fernandez-Reiriz, M.J. and Labarta, U., 2000. Metabolism of the mussel Mytilus galloprovincialis from two origins in the Ria de Arousa (north-west Spain). J. Mar. Biol. Ass. U.K., 80, 865-872.

Bayne, B.L., Bayne, C.J., Carefoot, T.C., Thompson, R.J., 1976. Physiological ecology of Mytilus Californianus. 1. Metabolism and energy balance. Oecologia 22, 211-228.

Boetius, A., Suess, E., 2004. Hydrate Ridge: a natural laboratory for the stusy of microbial life fuelled by methane from near-surface gas hydrates. Chem. Geol., 205, 291-310.

Boetius, A., Wenzhofer, F., 2013. Seafloor oxygen consumption fuelled by methane from cold seeps. Nature Geoscience 6, 725-734.

Caprais, J.C., Lanteri, N., Crassous, P., Noel, P., Bignon, L., Rousseaux, P., Pignet, P., Khripounoff, A., 2010. A new CALMAR benthic chamber operating by submersible, First application in the cold-seep environment of Napoli mud volcano (Mediterranean Sea). Limnol. Oceanogr. Methods 8, 304-312. 
Carritt, D. E., and Carpenter J. H., 1966. Comparison and evaluation of currently employed modifications of the Winkler method for determining dissolved oxygen in sea water: A NASCO report. J. Mar. Res. 24, 286-318.

Charlou J.L., Donval J.P., Fouquet Y., Ondreas H., Knoery J., Cochonat P., Levache D., Poirier Y., Jean-Baptiste P., Fourre E., 2004. Physical and chemical characterization of gas hydrates and associated methane plumes in the Congo-Angola Basin. Chem. Geol., 205, 405. Cordes, E.E., Arthur, M.A., Shea, K., Arvidson, R.S., Fisher, C.R., 2005. Modeling the mutualistic interactions between tubeworms and microbial consortia. PLoS 3-e77, 497-506. Cordes, E.E., Becker, E.L., Hourdez, S., Fisher, C.R., 2010. Influence of foundation species, depth, and location on diversity and 3 community composition at Gulf of Mexico lower slope cold-seeps. Deep-Sea Res. Part II 57, 1870-1881.

Cosel, R. von, Olu, K., 2009. Large Vesicomyidae (Mollusca: Bivalvia) from cold seeps in the Gulf of Guinea off the coasts of Gabon, Congo and northern Angola, Deep Sea Res. II 56 2350-2379.

Decker, C., Caprais J.-C., Khripounoff A., Olu K., 2012. First respiration estimates of coldseep vesicomyid bivalves from in situ total oxygen uptake measurements. C. R. Biol., 335, $261-270$

Felden, J., Wenzhöfer, F., Feseker, T., and Boetius, A.,2010. Transport and consumption of oxygen and methane in different habitats of the Hakon Mosby Mud Volcano (HMMV).

Limnol. Oceanogr.55, 2366-2380.

Felden, J., Ruff, S.E., Ertefai, T., Inagaki, F., Hinrichs, K.U., Wenzhöfer, F., 2014. Anaerobic methanotrophic community of a 5346-m-deep vesicomyid clam colony in the Japan Trench. Geobiology 12, 183-199.

Ferry, J.G., Lessner, D.J., 2008. Methanogenesis in Marine Sediments. Ann. N. Y. Acad. Sci. $1125,147-157$. 
Fischer, D., Sahling, H., Nöthen, K., Bohrmann, G., Zabel M., and Kasten, S., 2012.

Interaction between hydrocarbon seepage, chemosynthetic communities, and bottom water redox at cold-seeps of the Makran accretionary prism: insights from habitat-specific pore water sampling and modeling. Biogeosciences, 9, 2013-2031, 2012

Fonselius, S.H.,1983. Determination of hydrogen sulfide. In: Grasshof, K. (Ed.), Methods of sea-water analysis. Verlag Chemie, Kiel, pp. 73-84.

Gay, A., Lopez, M., Ondreas, H., Charlou, J.L., Sermondadaz, G., Cochonat, P.,2006.

Seafloor facies related to upward methane flux within a Giant Pockmark of the Lower Congo Basin. Mar. Geol.226, 81-95.

Grant, J., Thorpe, B., 1991. Effects of suspended sediment on growth, respiration and excretion of the soft-shell clam (Mya arenaria). Can. J. Fish. Aquat. Sci. 48, 1285-1292. Hashimoto, J., S. Ohta, T. Tanaka, H. Hotta, S. Matsuzawa, and H. Sakai. 1989. Deep-sea communities dominated by the giant clam, Calyptogena soyoae, along the slope foot of Hatsushima Island, Sagami Bay, central Japan. Palaeogeogr., Palaeoclimateol., Palaeoecol. $71,179-192$.

Hatcher, A., 1989. RQ of benthic marine invertebrates. Mar. Biol., 102, 445-452.

Holmes, R.M., Aminot, A., Kerouel, R., Hooker, B.A., Peterson, B.J., 1999. A simple and precise method for measuring ammonium in marine and freshwater ecosystems. Can. J. Fish. Aquat. Sci. 56, 1801-1808.

Huang, S.C., Newell, R.I.E., 2002. Seasonal variations in the rates of aquatic and aerial respiration and ammonium excretion of the ribbed mussel, Geukensia demissa (Dillwyn). J. Exp. Mar. Biol. Ecol.270, 241-255.

Jarnegren, J., Altin, D., 2006. Filtration and respiration of the deep living bivalve Acesta excavata (J.C. Fabricius, 1779) (Bivalvia; Limidae). J. Exp. Mar. Biol. Ecol. 334, 122-129. 
Jørgensen, B. B. and Boetius, A. (2007) Feast and famine - microbial life in the deep-sea bed. Nature, 5, 770-781.

Kaltin, S., Haraldsson, C., Anderson, L.G., 2005. A rapid method for determination of total dissolved inorganic carbon in seawater with high accuracy and precision. Mar. Chem. 96, 53. Kérouel, R., Aminot, A., 1997.Fluorometric determination of ammonia in sea and estuarine waters by direct segmented flow analysis. Mar. Chem. 57, 265-275.

Khripounoff, A., Vangriesheim, A., Babonneau, N., Crassous, P., Dennielou, B., Savoye, B., 2003. Direct observation of intense turbidity current activity in the Zaire submarine valley at 4000m water depth. Mar. Geol. 194, 151-158.

Knittel, K., Boetius, A., 2009. Anaerobic oxidation of methane: progress with an unknown process. Ann. Rev. Microbiol. 63, 311-334.

Koopmans, M., Martens D., Wijffels R.H., 2010. Growth Efficiency and Carbon Balance for the Sponge Haliclona oculata. Mar Biotechnol 12, 340-349.

Krylova, E. M., Sahling H, 2010. Vesicomyidae (Bivalvia): current taxonomy and distribution. PLoS ONE 5, 1-9.

Levin, L. A., Ziebis, W., Mendoza, G. F., Growney, V. A., Tryon, M. D., Brown, K. B., Mahn, C., Gieskes, J. M., and Rathburn, A. E., 2003. Spatial heterogeneity of macrofauna at northern California methane seeps: influence of sulfide concentration and fluid-flow. Mar. Ecol.-Prog. Ser., 265, 123-139.

Levin, L. A., 2005. Ecology of cold-seep sediments: interactions of fauna with flow, chemistry and microbes. Oceanogr. Mar. Biol. Annu. Rev. 43, 1-46.

Levin, L. A., Mendoza, G. F., Gonzalez, J. P., Thurber, A. R., Cordes, E. E., 2010. Diversity of bathyal macrofauna on the northeastern Pacific margin: the influence of methane seeps and oxygen minimum zones, Mar. Ecol., 31, 94-110. 
Lichtschlag, A., J. Felden, V. Bruchert, A. Boetius, and D. De Beer. 2010. Geochemical processes and chemosynthetic primary production in different thiotrophic mats of the $\mathrm{Ha}^{\circ} \mathrm{kon}$ Mosby Mud Volcano (Barents Sea). Limnol. Oceanogr. 55: 931-949.

Linke, P., Wallmann, K., Suess, E., Hensen, C., Rehder, G., 2005. In situ benthic fluxes from an intermittently active mud volcano at the Costa Rica convergent margin. Earth Planet. Sci. Lett., 235, 79-95.

Marcon Y, Ondréas H. Sahling H, Bohrmann G, Olu K., 2014a. Fluid flow regimes and growth of a giant pockmark. Geology 42: 63-66.

Marcon, Y., Sahling, H., Allais, A. G., Bohrmann, G., Olu. K., 2014b. Distribution and temporal variation of mega-fauna at the Regab pockmark (Northern Congo Fan), based on a comparison of videomosaics and geographic information systems analyses. Mar. Ecol., 35, $77-95$

Olu, K., Duperret, A., Sibuet, M., Foucher, J.-P., Fiala-Médioni., A., 1996. Structure and distribution of cold-seep communities along the Peruvian active margin: relationship to geological and fluid patterns. Mar. Ecol. Prog. Ser. 132, 109-125.

Olu-Le Roy, K., Caprais, J.-C., Fifis, A., Fabri, M.-C., Galéron, J., Budzinsky, H., Le Menach, K., Khripounoff, A., Ondreas, H., Sibuet, M., 2007. Cold-seep assemblages on a giant pockmark off West Africa: spatial patterns and environmental control. Mar. Ecol., 28, $115-130$.

Olu, K., Caprais, J. C., Galéron, J., Causse, R., von Cosel, R., Budzinski, H., Le Ménach, K., Le Roux, C., Levaché, D., Khripounoff, A., and Sibuet, M., 2009. Influence of seep emission on the non-symbiont-bearing fauna and vagrant species at an active giant pockmark in the Gulf of Guinea (Congo-Angola margin), Deep-Sea Res. Part II 56, 2380-2393.

Ondréas, H., Olu, K., Fouquet, Y., Charlou, J. L., Gay, A., Dennielou, B., Donval, J. P., Fifís, A., Nadalig, T., Cochonat, P., Cauquil, E., Bourillet, J. F., Le Moigne, M., and Sibuet, M., 
2005. ROV study of a giant pockmark on the Gabon continental margin. Geo- Mar. Lett, 25, 281-292.

Pop Ristova P., Wenzhofer F., Ramette A., Zabel M., Fischer D., Kasten S., Boetius A., 2012. Bacterial diversity and biogeochemistry of different chemosynthetic habitats of the REGAB cold-seep (West African margin, 3160m water depth). Biogeosciences, 9, 5031-5048.

Rabouille, C., Caprais, J.C., Lansard, B., Crassous, P., Dedieu, K., Reyss, J.L., Khripounoff, A., 2009. Organic matter budget in the Southeast Atlantic continental margin close to the Congo Canyon: In situ measurements of sediment oxygen consumption. Deep-Sea Res. Part II $56,2223-2238$.

Ritt, B., Pierre, C., Gauthier, O., Wenzhöfer, F., Boetius, A., Sarrazin, J., 2011. Diversity and distribution of cold-seep fauna associated with different geological and environmental settings at mud volcanoes and pockmarks of the Nile Deep-Sea Fan, Mar. Biol., 158, 1187-1210. Sahling, H., Rickert, D., Lee, R.W., Linke, P., Suess, E., 2002. Macrofaunal community structure and sulfide flux at gas hydrate deposits from the Cascadia convergent margin, NE Pacific. Mar. Ecol. Prog. Ser. 231, 121-138.

Sarradin, P.-M., Caprais, J.C., 1996. Analysis of dissolved gases by headspace sampling, gas chromatography with columns and detectors commutation. Preliminary results. Anal. Com. $33,371-373$.

Savoye, B., Babonneau, N., Denniellou, B., Bez, M., 2009. Geological overview of the Angola-Congo margin. The Congo deep-sea fan and its submarine valleys. Deep-Sea Res. Part II 56, 2169-2182.

Sibuet, M., Olu, K.,1998. Biogeography, biodiversity and fluid dependence of deep-sea coldseep communities at active and passive margins. Deep-Sea Res. Part II 45, 517-567. Sibuet, M., Olu, K., 2002. Cold-seep communities on continental margins: structure and quantitative distribution relative to geological and fluid venting patterns, in ocean margin 
systems, edited by: Wefer, G., Billett, D., Hebbeln, D., Jorgensen, B. B., Schlueter, M., van Weering, T. C. E., p 501, Springer-Verlag berlin Heidelberg New York, Heidelberg. Sommer, S., Pfannkuche, O., Linke, P., Luff, R., Greinert, J., Drews, M., Gubsch, S., Pieper, M., Poser, M., and Viergutz, T.,2006. Efficiency of the benthic filter: Biological control of the emission of dissolved methane from sediments containing shallow gas hydrates at Hydrate Ridge, Global Biogeochem. Cy 20, GB2019.

Sommer, S., Turk, M., Kriwanek, S., Pfannkuche, O., 2008. Gas exchange system for extended in situ benthic chamber flux measurements under controlled oxygen conditions: First application - Sea bed methane emission measurements at Captain Arutyunov mud volcano. Limnol. Oceanogr. Methods 6, 23-33.

Sommer, S., Linke, P., Pfannkuche, O., Niemann, H., and Treude, T., 2010. Benthic respiration in a seep habitat dominated by dense beds of ampharetid polychaetes at the Hikurangi Margin (New Zealand ). Mar. Geol. 272, 223-232.

Suess, E., Torres, M.E., Bohrmann, G., Collier, R.W., Greinert, J., Linke, P., Rehder, G., Trehu, A., Wallmann, K., Winckler, G., Zuleger, E.,1999. Gas hydrate destabilization: enhanced dewatering, benthic material turnover and large methane plumes at the Cascadia convergent margin. Earth Planet. Sci. Lett. 170, 1-15.

Torres, M. E., McManus, J., Hammond, D. E., de Angelis, M. A., Heeschen, K. U., Colbert, S. L., Tryon, M. D., Brown, K. M., and Suess, E., 2002. Fluid and chemical fluxes in and out of sediments hosting methane hydrate deposits on Hydrate Ridge, OR, I: Hydrological provinces, Earth Planet. Sci. Lett. 201, 3-4, 525-540.

Treude, T., Boetius, A., Knittel, K., Wallmann, K., Jorgensen, B.B., 2003. Anaerobic oxidation of methane above gas hydrates at Hydrate Ridge, NE Pacific Ocean. Mar. Ecol. Prog. Ser. 264, 1-14. 
Vangriesheim, A., Khripounoff, A., Crassous, P.,2009. Turbidity events observed in situ along the Congo submarine channel. Deep-Sea Res. Part II 56, 2208-2222.

Wallmann, K., Linke, P., Suess, E., Bohrmann, G., Sahling, H., Schlüter, M., Dählmann, A., Lammers, S., Greinert, J., von Mirbach, N., 1997. Quantifying fluid flow, solute mixing, and biogeochemical turnover at cold vents of the eastern aleutian subduction zone. Geochim.

Cosmochim. Acta 61, 5209-5219.

Whiticar, M.J., 1999. Carbon and hydrogen isotope systematics of bacterial formation and oxidation of methane. Chem. Geol. 161, 291-314.

Wilbur, A.E., Hilbish, T.J., 1989. Physiological energetics of the ribbed mussel Geukensia Demissa (Dillwyn) in response to increased temperature. J. Exp. Mar. Biol. Ecol. 131, 161170. 
Table 1: Characteristics of the study stations

\begin{tabular}{|c|c|c|c|c|c|}
\hline Date & Station (Marker) & \multicolumn{2}{|c|}{ Position } & Depth (m) & Dive \\
\hline 4 Feb. 2011 & $\begin{array}{l}\text { Regab SW } \\
\text { (South-West) }\end{array}$ & S $5^{\circ} 47.979$ & E $9^{\circ} 42.474$ & 3154 & pl 425-3 \\
\hline 8 Feb. 2011 & Regab Center & S $5^{\circ} 47.868$ & E $9^{\circ} 42.688$ & 3156 & pl 427-5 \\
\hline 15 Feb. 2011 & Guiness Kilkenny & S $1{ }^{\circ} 34.602$ & E $8^{\circ} 31.809$ & 687 & pl 433-11 \\
\hline 15 Feb. 2011 & Guiness Harp & S $1{ }^{\circ} 34.646$ & E $8^{\circ} 32.913$ & & pl 433-11 \\
\hline 21 Feb. 2011 & Lobe A & S $6^{\circ} 26.904$ & Е $6^{\circ} 01.927$ & 4750 & pl 435-13 \\
\hline 23 Feb. 2011 & Lobe $\mathrm{C}$ & S $6^{\circ} 42.079$ & E $5^{\circ} 29.289$ & 5072 & pl 437-15 \\
\hline
\end{tabular}


Table 2: Gas fluxes at the water-sediment interface as measured under the Calmar chamber at each of the six study stations

\begin{tabular}{lcccccc}
\hline Station & Regab SW & $\begin{array}{c}\text { Regab } \\
\text { Center }\end{array}$ & $\begin{array}{c}\text { Guiness } \\
\text { Kilkenny }\end{array}$ & $\begin{array}{c}\text { Guiness } \\
\text { Harp }\end{array}$ & Lobe A & Lobe C \\
\hline & & & & & & \\
\hline $\mathrm{O}_{2}\left(\mathrm{mmol} \mathrm{m}^{-2} \mathrm{~d}^{-1}\right)$ & -272.2 & -433.4 & -28.5 & -271.0 & -157.4 & -345.6 \\
\hline $\mathrm{CO}_{2}\left(\mathrm{mmol} \mathrm{m}^{-2} \mathrm{~d}^{-1}\right)$ & 50 & 86 & 95.5 & 155 & 36 & 1857 \\
\hline $\mathrm{RQ}=\mathrm{CO}_{2} / \mathrm{O}_{2}$ & 0.2 & 0.2 & 3.3 & 0.6 & 0.2 & 5.4 \\
\hline $\mathrm{NH}_{4}{ }^{+}\left(\mathrm{mmol} \mathrm{m}^{-2} \mathrm{~d}^{-1}\right)$ & 8.9 & 10.2 & n.d. & n.d. & 7.5 & 71.8 \\
\hline${\mathrm{Atomic} \mathrm{O}: \mathrm{N} \mathrm{ratio}^{-1}}$ & 12 & 17 & n.d. & n.d. & 8 & 2 \\
\hline $\mathrm{CH}_{4}{ }^{+}\left(\mathrm{mmol} \mathrm{m}^{-2} \mathrm{~d}^{-1}\right)$ & 12.3 .0 & 45.8 .0 & n.d. & n.d. & 1.8 & 139.0 \\
\hline $\mathrm{H}_{2} \mathrm{~S}\left(\mathrm{mmol} \mathrm{m}^{-2} \mathrm{~d}^{-1}\right)$ & $<20$ & $<20$ & $<20$ & 156 & $<20$ & $<20$ \\
\hline
\end{tabular}


Table 3: Density and biomass of vesicomyids at each station calculated from photographs and corers. Standard deviations (SD) are given in parentheses.

\begin{tabular}{|c|c|c|c|c|c|c|}
\hline Station & Regab SW & Regab Center & Guiness Kilkenny & Guiness Harp & Lobe A & Lobe C \\
\hline Vesicomyid species & $\begin{array}{l}\text { Christineconcha } \\
\text { regab }\end{array}$ & $\begin{array}{l}\text { Christineconcha } \\
\text { regab }\end{array}$ & $\begin{array}{c}\text { Calyptogena } \\
\text { valdiviae }\end{array}$ & $\begin{array}{c}\text { Calyptogena } \\
\text { valdiviae }\end{array}$ & $\begin{array}{l}\text { Christineconcha } \\
\text { regab }\end{array}$ & $\begin{array}{l}\text { Christineconcha } \\
\text { regab }\end{array}$ \\
\hline \multicolumn{7}{|l|}{ Density (ind. $\mathrm{m}^{-2}$ ) } \\
\hline & 310 & 610 & 75 & 278 & 506 & 748 \\
\hline $\begin{array}{l}\text { Mean individual biomass ( } \mathrm{g} \mathrm{dw} \\
\text { ind }^{-1} \text { ) (SD) }\end{array}$ & $2.33(0.30)$ & $2.91(0.74)$ & $1.13(0.88)$ & $0.67(0.13)$ & $1.55(0.79)$ & $0.84(0.48)$ \\
\hline Biomass (g dry weight $\mathrm{m}^{-2}$ ) & 723 & 1774 & 85 & 187 & 784 & 629 \\
\hline
\end{tabular}




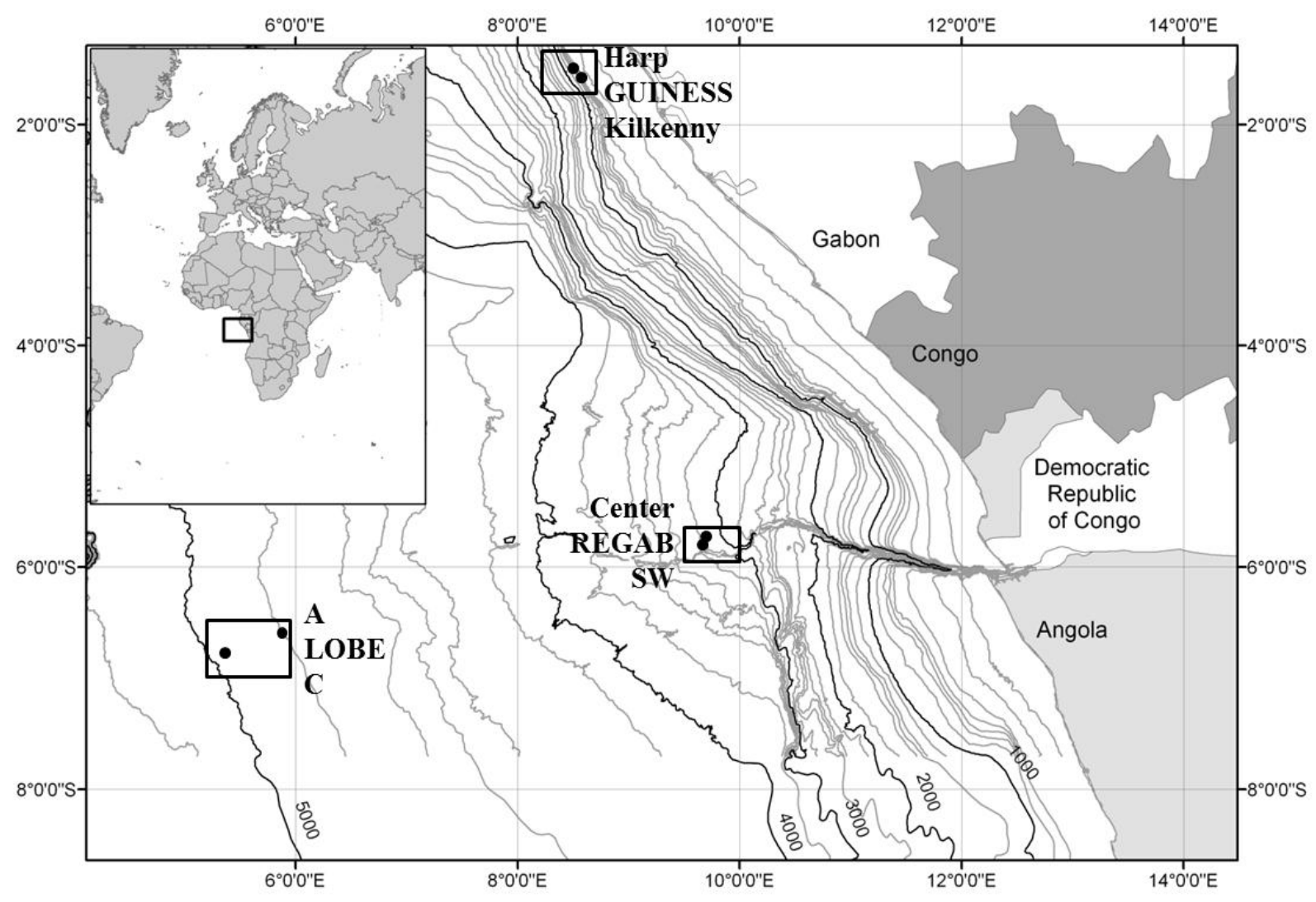

Figure 1 : Location of the six stations in the Gulf of Guinea. 


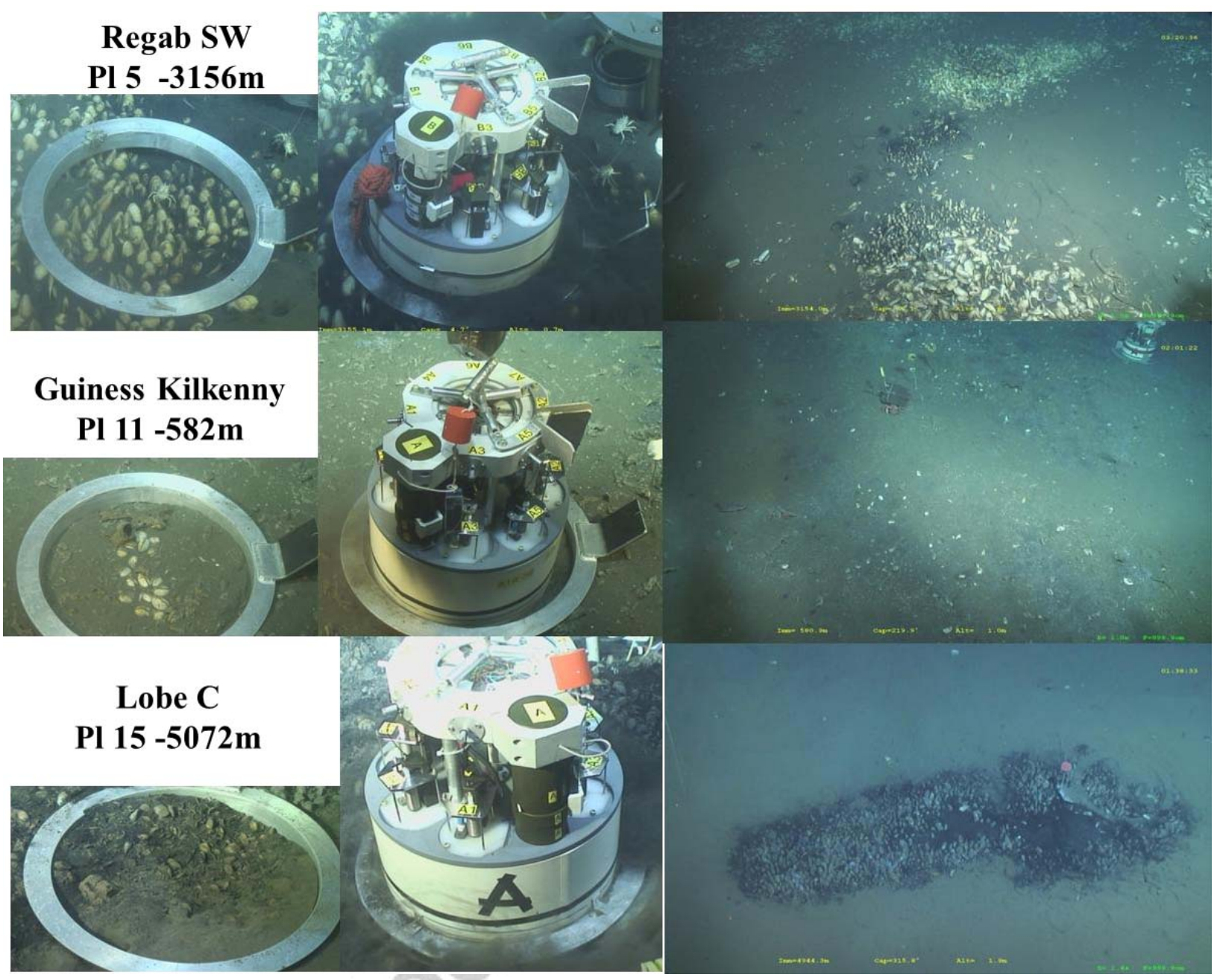

Figure 2: Examples of deployments of the Calmar benthic chamber during the WACS cruise. Photographs on the left: Ring (50 cm diameter) delimiting the Calmar measurement surface area. Photographs in the center: Calmar in position in the ring. Photographs on the right: general view of the different stations where Calmar was deployed. 

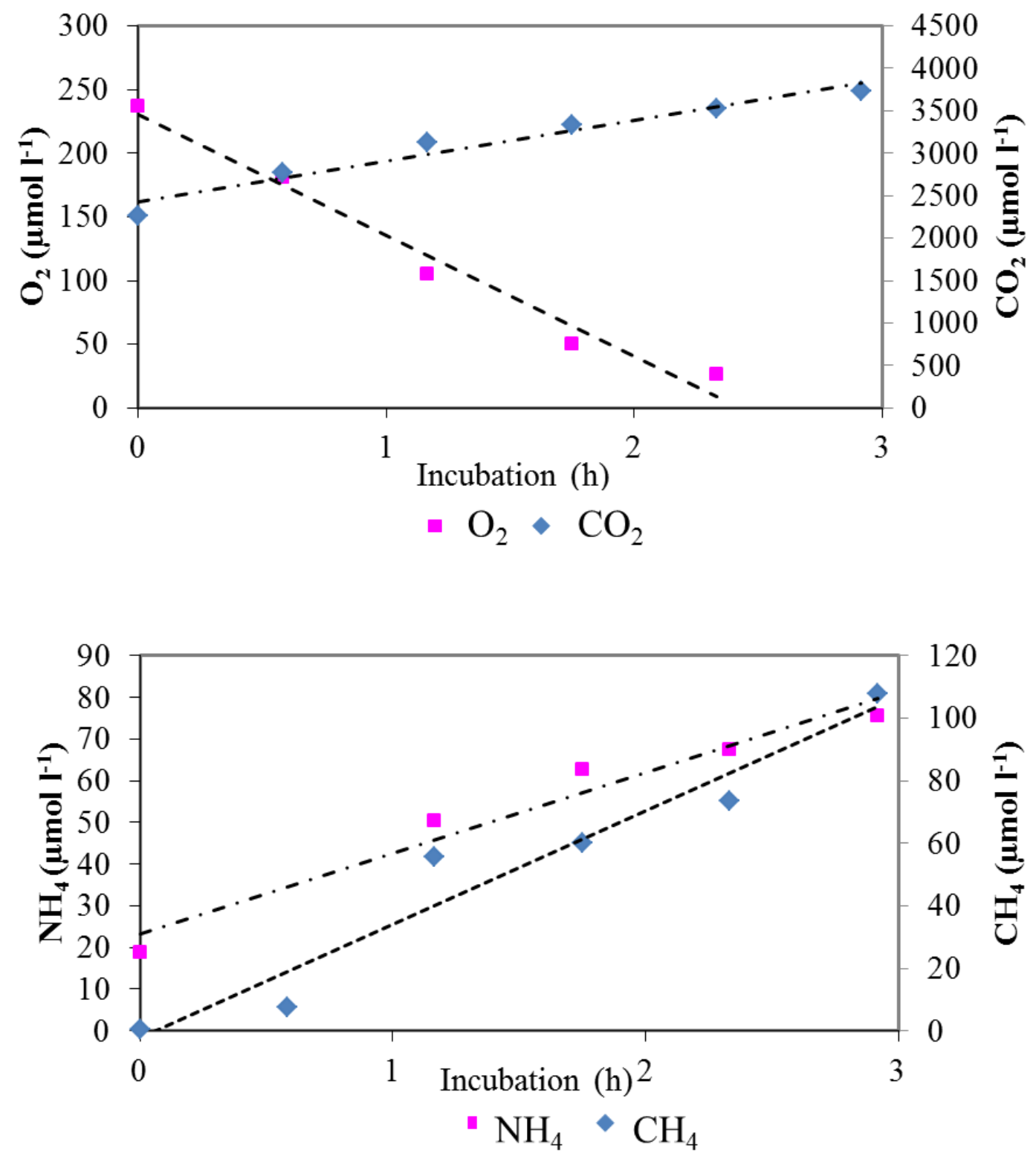

Figure 3: Gas and ammonium values measured over time using the Calmar benthic chamber at the Regab C station (dive p115-437) 


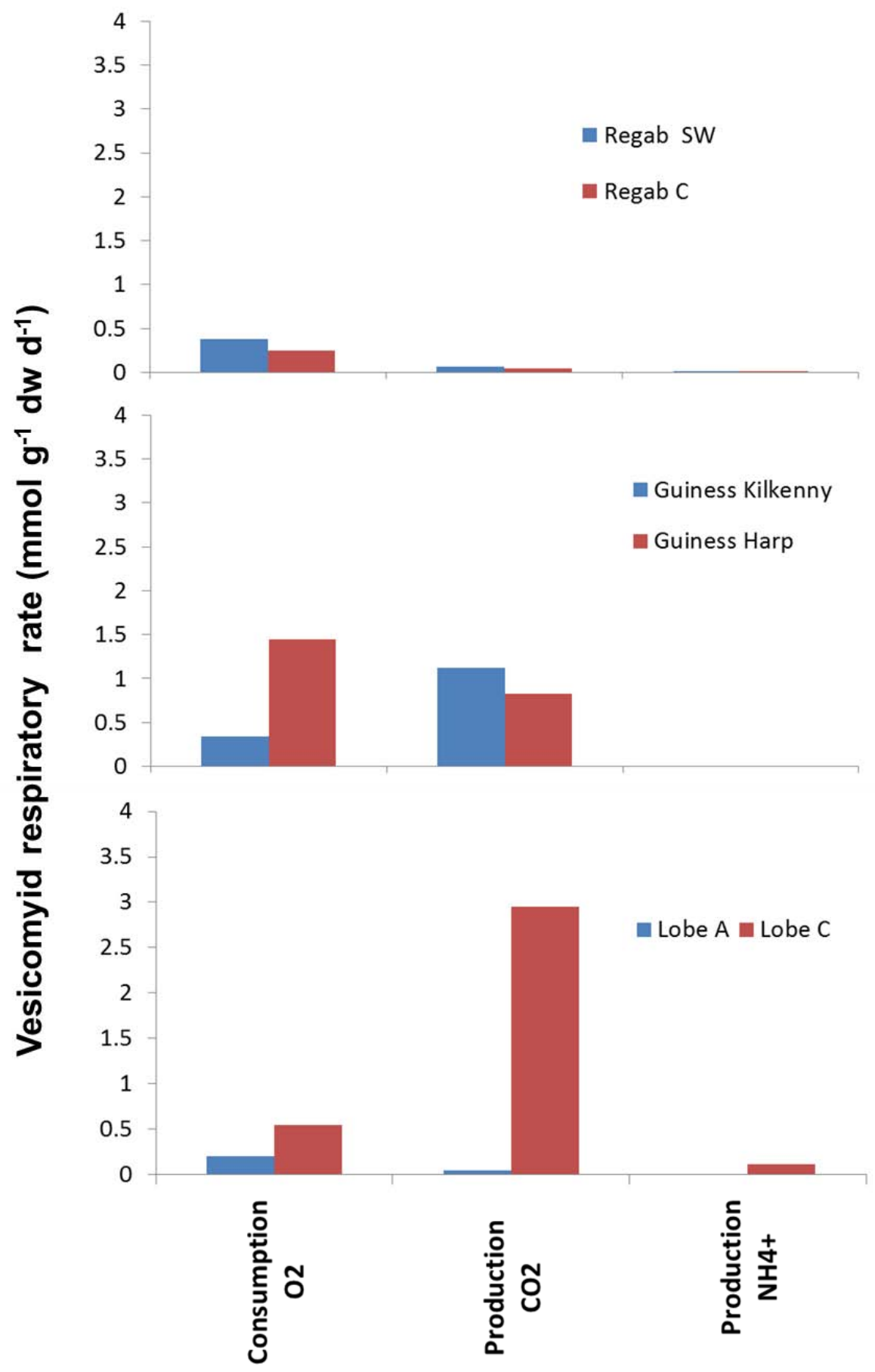

Figure 4: Estimated vesicomyid respiration rates at the six study stations. 

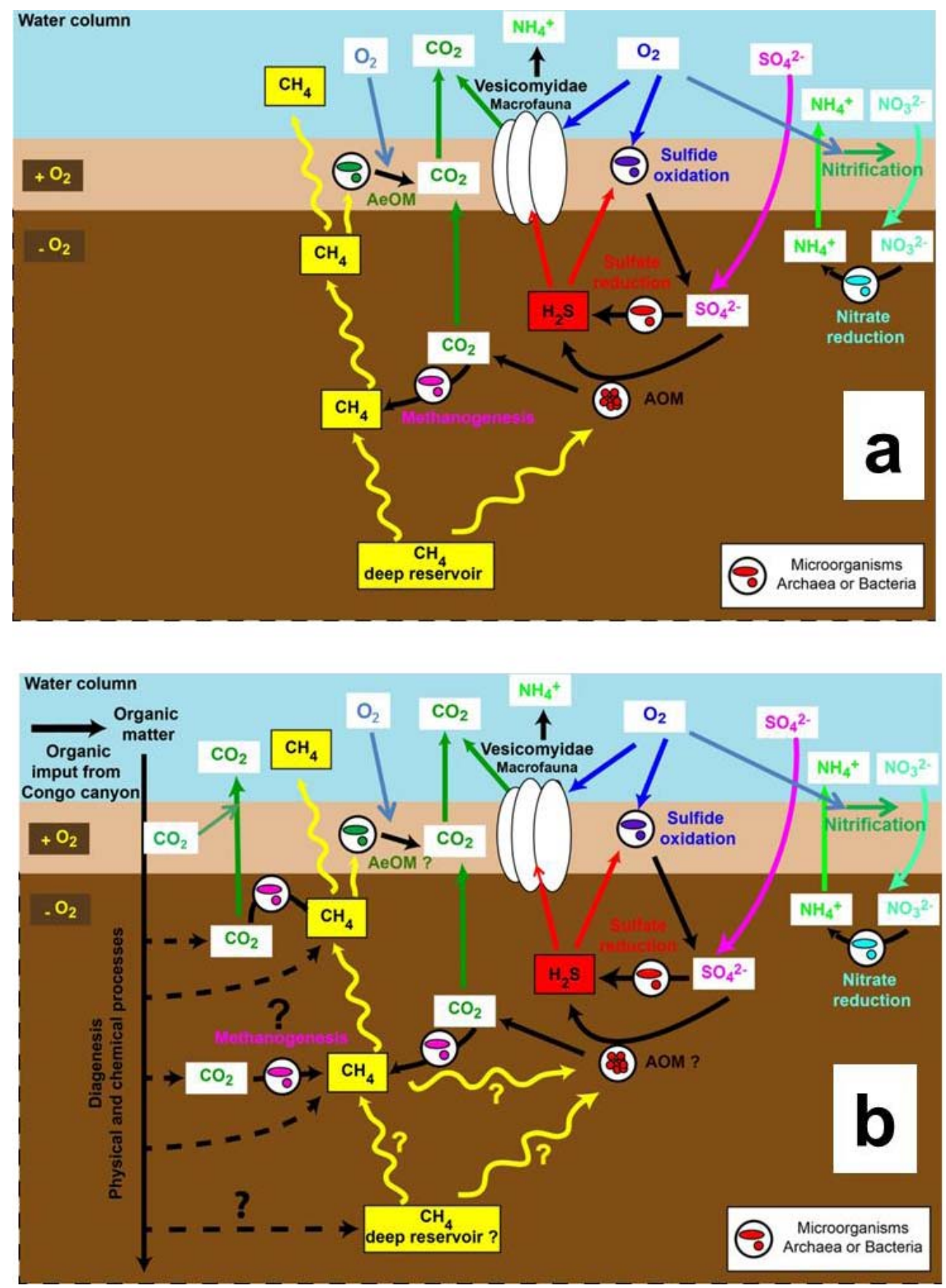

Figure 5: Schematic diagram of vesicomyid habitats. (a) The Regab and Guiness cold seeps with major gas transport pathways and transformation in the surficial sediment. (b) The Lobe site where the origin of the methane is unknown, but probably biogenic. $\mathrm{AeOM}=$ aerobic oxidation of methane, $\mathrm{AOM}=$ anaerobic oxidation of methane. 